\title{
Occurrence and vertical flux of faecal pellets of probably protozoan origin in the southeastern Weddell Sea (Antarctica)*
}

\author{
Eva-Maria Nöthig ${ }^{1}$, Bodo von Bodungen ${ }^{2}$ \\ ${ }^{1}$ Alfred-Wegener-Institut für Polar- und Meeresforschung, Am Handelshafen 12, D-2850 Bremerhaven, Federal Republic of \\ Germany \\ ${ }^{2}$ Sonderforschungsbereich 313, Christian-Albrechts-Universität Kiel, Olshausenstr. 40, D-2300 Kiel, Federal Republic of \\ Germany
}

\begin{abstract}
Amount of faecal material in the water column and in sediment traps deployed at 7 different stations was investigated during a cruise of RV 'Polarstern' off Vestkapp $\left(73^{\circ} \mathrm{S}, 19^{\circ} \mathrm{W}\right)$, Weddell Sea, Antarctica. Numerous small round, ellipsoidal or triangular pellets (30 to $150 \mu \mathrm{m}$ ) were identified in the water column and the traps. Most of the pellets contained intact, but empty, frustules of the abundant diatoms. We suggest that these small pellets were produced by protozoan grazers (ciliates, heterotrophic dinoflagellates, radiolarians and probably foraminifers). These pellets occurred in numbers up to $214 \mathrm{l}^{-1}$ in the water column and contributed significantly ( $36 \%$ of total sedimented faeces volume in traps) to vertical particle transport of empty but intact diatom frustules from the euphotic zone to deeper water layers. The greatest part of the remaining faecal material in the sediment traps consisted of larger, nearly round faecal pellets $(150$ to $300 \mu \mathrm{m})$. These faecal pellets are of unknown origin, but could have been produced by small metazoans.
\end{abstract}

\section{INTRODUCTION}

In recent years, study of vertical particle flux in the sea has been greatly intensified. Faeces are one of the dominant particle classes recognizable in material collected by sediment traps. Trap collections from different regions of the oceans exhibit great diversity in their composition, and many of the recurring, recognizable particle types have not yet been identified with regard to producer organisms, although they are clearly faeces. Faeces produced by metazooplankton is thought to be one of the most important components of fast-sinking material (e.g. Angel 1984). Large metazoa such as euphausiids and salps are one important group that produce large, fast-sinking faeces (von Bodungen et al. 1987, Bathmann 1988). On the other hand, faeces do not seem to contribute significantly to vertical flux out of the euphotic zone (e.g. Alldredge et al. 1987, Pilskaln \& Honjo 1987). Copepod faeces are retained

\footnotetext{
- Contribution No. 199 of the Alfred-Wegener-Institut for Polar and Marine Research
}

within the mixed layer as a result of coprophagy (Smetacek 1980, 1984, Bathmann et al. 1987) or coprorhexy (Lampitt et al. 1989); the latter is due to breakage and disintegration by grazers.

Little is known about the production and fate of protozoan faeces. The potential role of protozooplankton in the pelagic marine environment of the Antarctic Ocean has been recognized over the past 5 yr (e.g. Hewes et al. 1985). In general, the grazing impact of protozoans on phytoplankton assemblages is poorly known, and information on the egestion products of protozooplankton and their fate is lacking. One possible fate of faeces is sedimentation. Other possible 'faecal pellet pathways' are coprophagy or disintegration of pellets in the surface layers of the water column.

In Antarctic waters, little information on vertical particle flux from sediment trap deployments exists. It is known that faeces can play a major role in vertical particle transport in the Southern Ocean (Fukuchi \& Sasaki 1981, Dunbar 1984, Wefer et al. 1988). Longand short-term investigations of flux have been carried out in the eastern Bransfield Strait (Schnack 1985, von Bodungen 1986, von Bodungen et al. 1986, von 
Table 1. Trap numbers, station numbers, locations, dates, depths, and times of deployment off Vestkapp. 'Moored traps; the others were free drifting traps. (Trap 4, consisting of 2 traps at $80 \mathrm{~m}$ and $350 \mathrm{~m}$, was moored at Stn 286 and recovered at the same location 10 d later now referred to as Stn 314

\begin{tabular}{|c|c|c|c|c|c|}
\hline Trap & Station & Location & Date (1985) & Depth (m) & Time (d) \\
\hline $1^{*}$ & 274 & $72^{\circ} 35^{\prime} \mathrm{S}, 18^{\circ} 09^{\prime} \mathrm{W}$ & $28 \mathrm{Jan}$ & 80 & 1.58 \\
\hline 2 & 280 & $72^{\circ} 15^{\prime} \mathrm{S}, 18^{\circ} 21^{\prime} \mathrm{W}$ & $30 \mathrm{Jan}$ & 100 & 0.43 \\
\hline $3^{\circ}$ & 284 & $72^{\circ} 31^{\prime} \mathrm{S}, 17^{\circ} 17^{\prime} \mathrm{W}$ & $31 \mathrm{Jan}$ & 80 & 1.11 \\
\hline \multirow[t]{2}{*}{$4^{\circ}$} & $286 / 314$ & $73^{\circ} 16^{\prime} \mathrm{S}, 20^{\circ} 24^{\prime} \mathrm{W}$ & 1 Feb to & 80 & 10.43 \\
\hline & & & 12 Feb & 350 & 10.43 \\
\hline 5 & 340 & $72^{\circ} 3^{\prime} \mathrm{S}, 18^{\circ} 53^{\prime} \mathrm{W}$ & $17 \mathrm{Feb}$ & 100 & 0.42 \\
\hline 6 & 347 & $72^{\circ} 48^{\prime} \mathrm{S}, 19^{\circ} 57^{\prime} \mathrm{W}$ & $19 \mathrm{Feb}$ & 100 & 0.53 \\
\hline 7 & 348 & $72^{\circ} 56^{\prime} \mathrm{S}, 19^{\circ} 10^{\prime} \mathrm{W}$ & $20 \mathrm{Feb}$ & 100 & 0.24 \\
\hline
\end{tabular}

Bodungen et al. 1987, Wefer et al. 1988) and in the central Weddell Sea (Fischer et al. 1988).

The results we present here were obtained as part of an intensive sampling programme carried out during a cruise of the RV 'Polarstern' (Antarktis III, 3; Hempel 1985). Accounts of pelagic ecology and detailed results of the composition of phyto- and protozooplankton in the investigation area are given elsewhere (von Bodungen et al. 1988, Nöthig 1988). In this paper we focus mainly on results derived from microscopic analysis of small faecal pellets found in the water column and in sediment traps and discuss them within the framework of biological processes occurring in the water column during the investigation.

\section{MATERIAL AND METHODS}

A box consisting of 4 transects (each with 5 to 7 stations) normal to the shelf ice coast off Vestkapp $\left(73^{\circ} \mathrm{S}, 19^{\circ} \mathrm{W}\right)$ was monitored on 2 occasions during the RV 'Polarstern' cruise to the southeastern Weddell Sea. Stations were occupied from 22 January to 1 February (Vestkapp I) and again from 12 to 21 February 1985 (Vestkapp II). Samples for determination of phyto- and protozooplankton composition and numbers of faecal pellets in the water column were taken from discrete depths ( 10 to 12 depths between 0 and $300 \mathrm{~m}$ and up to 5 depths below $300 \mathrm{~m}$ ) with Niskin bottles mounted on a CTD rosette sampler. The samples were fixed with hexamine-buffered formalin to a final concentration of $0.5 \%$, and stored in brown glass bottles. Inverted microscope counts (Utermöhl 1958) were carried out on $50 \mathrm{ml}$ samples from the upper $100 \mathrm{~m}$ water layer. Larger samples (1000 to $3000 \mathrm{ml}$ ) from deeper water (>100 m) were concentrated on a $2 \mu \mathrm{m}$ polycarbonate filter and then rinsed from the filter and diluted with $0{ }^{\circ} \mathrm{C}$ filtered seawater $(30$ to $100 \mathrm{ml})$ into a brown glass bottle, fixed and counted like the other samples.

Estimates of phytoplankton and protozooplankton carbon were obtained from the counts by measuring the cells, determining the plasma volume according to Edler (1979), and then multiplying the plasma volume by 0.11 (Strathmann 1967). For faecal pellets, only the volume was calculated.

Vertical particle flux was determined by sediment traps (enlarged Kiel funnel type; Zeitzschel et al. 1978), deployed on 7 occasions for short periods as free drifting or moored traps below the euphotic zone (Table 1). The traps were equipped with 1 collecting jar, each containing 1 drop of chloroform as preservative. In aliquots of the collected material, stored in 1 to $2 \%$ hexamine-buffered formalin seawater solution, intact plasma containing phytoplankton cells and faecal pellets were counted as described above. Dry weight was measured using precombusted GF/C glass fiber filters after Lenz (1971). On the same filters total particulate organic carbon (POC) and nitrogen (PON) of nonformalin-fixed sedimented material were measured with a Hewlett-Packard CHN analyzer (185b).

\section{RESULTS}

\section{Water column}

Phytoplankton biomass was dominated by flagellates (colonies of Phaeocystis sp. and Distephanus speculum) and small diatoms except at the stations closest to the shelf ice coast where larger diatoms were numerous. Larger diatoms were also found below a meltwaterinduced pycnocline at $30 \mathrm{~m}$. In the surface water

Fig. 1. Faecal pellets collected in the water column and in the sediment traps (bars $=100 \mu \mathrm{m}$ ). (a) A Gyrodinium with an ingested chain of pennate diatoms. (b) A dinoflagellate with vanous ingested diatoms (c, d) Small faecal pellets (30 to $150 \mu \mathrm{m}$ ) from the water column; empty frustules of different diatoms can be seen. (e) Small faecal pellet found in the trap material. (f, g) Faecal pellets $(>150 \mu \mathrm{m})$ found in the trap material 

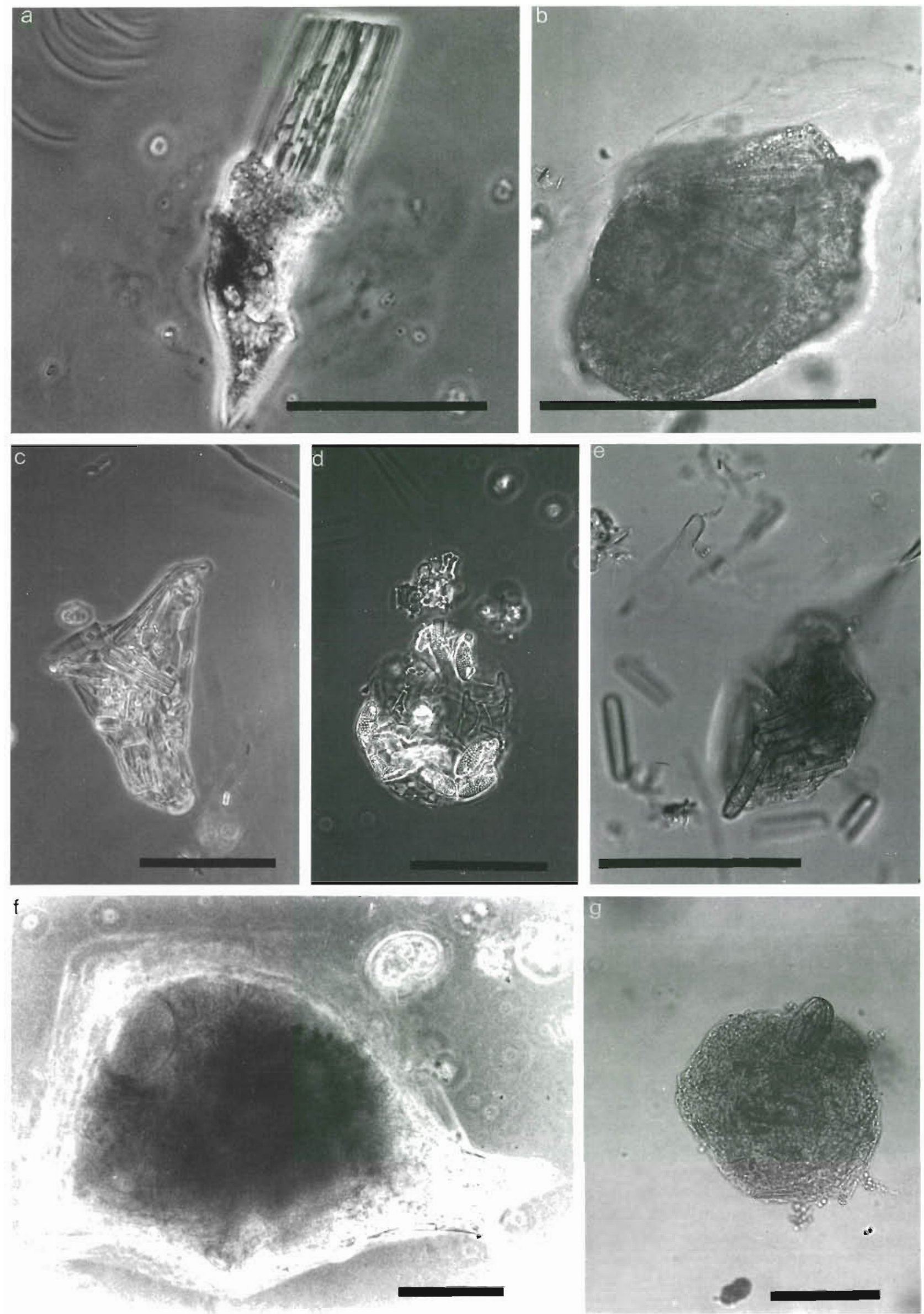
masses, protozooplankton biomass was high, consisting mainly of naked ciliates (average $54 \%$ of protozooplankton carbon) and heterotrophic dinoflagellates $(42 \%)$. Protozooplankton contributed, on average, $42 \%$ during Vestkapp I and $16 \%$ during Vestkapp II to combined phytoplankton and protozooplankton carbon. The large heterotrophic dinoflagellates often contained ingested diatoms of abundant species in their food vacuoles (Fig. 1a, b), indicating active grazing on the in situ phytoplankton community (Nöthig 1988, Nöthig et al. unpubl.). Larger protozoans such as foraminifers and radiolarians were present in low numbers in most of the samples, but were not assessed quantitatively by the method employed. Numbers of larger zooplankton (sampled by standard nets) were generally low throughout the investigation period and dominated by copepods, appendicularians and calyptopis-1 larvae of krill Euphausia superba (Hubold et al. 1988).

One striking feature in almost all water column samples counted with the microscope was the occurrence of round, ellipsoidal or triangular faecal pellets ranging in size from ca 30 to $150 \mu \mathrm{m}$ (Fig. 1c, d). In all water column samples, faecal pellets of fairly small size - most smaller than $100 \mu \mathrm{m}$ in diameter - were encountered, whereas in the sediment traps (see below) larger, round to oval faecal pellets similar in shape to the small water column faecal pellets were also observed (Fig. 1f, g).

The faecal pellets counted at the individual stations are listed in Table 2. Numbers of faecal pellets in each discrete sample counted were relatively low (between 0 and 30 pellets per counted volume and depth). A similar trend could be observed comparing stations with each other; counts from different depth intervals for each Vestkapp I as well as Vestkapp II stations have been added and are depicted in Fig. 2a, b. This procedure yields a significant number of faecal pellets to characterize each water column. During Vestkapp I, highest numbers of small faecal pellets $\left(68 \mathrm{I}^{-1}\right.$; range 0 to 214 ) were found within the upper $100 \mathrm{~m}$ of the water column, and numbers decreased continuously with depth (Fig. 2a). No small faecal pellets were found at depths below $500 \mathrm{~m}$. During Vestkapp II, however, the maximum in faecal pellet numbers $\left(37 \mathrm{l}^{-1}\right.$; range 0 to 166) was observed in 300 to $500 \mathrm{~m}$ water depth. Even at depths greater than $500 \mathrm{~m}$, some small faecal pellets were observed. Numbers in the upper $300 \mathrm{~m}$ were significantly lower $\left(<261^{-1}\right.$; range 0 to 80$)$ than during Vestkapp I (Fig. 2b). For the upper $100 \mathrm{~m}$ of the water column enough data are available to describe the above-mentioned trend. However, values obtained from below $100 \mathrm{~m}$ should be interpreted with care, because fewer samples were counted. Integrated over a $1000 \mathrm{~m}$ water column, total faecal pellet numbers during Vestkapp II $\left(16 \times 10^{6} \mathrm{~m}^{-2}\right)$ were 1.6 times higher than during Vestkapp $I\left(10 \times 10^{6} \mathrm{~m}^{-2}\right)$.

\section{Traps}

Material from the different traps indicated a relatively low sedimentation rate (Fig. 3). On a daily basis, less than $0.6 \%$ of the POC and $0.5 \%$ of phytoplankton carbon in the water column above the trap sedimented out. The contribution of phytoplankton to the sedimented POC was less than $6 \%$, with the exception of Stns 274 and 284 where it contributed 20 and $37 \%$, respectively, Sedimentation pattern of the faecal material followed that of total dry weight of trap material.

The collected recognizable material consisted mostly of round ellipsoidal or triangular faecal pellets with a mean size range from 30 to $300 \mu \mathrm{m}$ in diameter (Fig. 1e to $\mathrm{g})$. The faecal pellets encountered were separated into 2 size classes: 30 to $150 \mu \mathrm{m}$ and 150 to $300 \mu \mathrm{m}$. Like the faecal pellets found in the water column samples, most of the pellets in the traps contained unbroken diatom frustules or even diatom chains, but almost always without any plasma content. In addition to these types of faecal pellets, some string-shaped krill faeces (only found at Stns 280 and 347) and a few faecal pellets of copepods (at almost every station) were found. These obviously metazoan faeces are not included in Fig. 4; their numbers and volumes were negligible. Numbers of the smaller pellets - ranging from 9 to $8600 \times 10^{3} \mathrm{~m}^{-2} \mathrm{~d}^{-1}$ for the individual samples - exceeded numbers of the larger pellets ( 2 to $252 \times 10^{3}$ $\mathrm{m}^{-2} \mathrm{~d}^{-1}$ ) in each individual sample (Fig. 4a). The latter, however, contributed $64 \%$ by volume to the vertical faecal flux as a mean for all trap measurements because of their much larger size. The small faecal pellets therefore contributed less than $36 \%$ to sedimented faecal volume (Fig. 4b). A comparison of the actual standing stock of the small pellets in the water column with the numbers of the faecal pellets counted in the trap material showed that a mean of 28.5 $\%$ sedimented out per day. This is about 2 orders of magnitude higher than the observed POC and PPC flux of the standing stock of POC and PPC above the traps, clearly indicating selective sedimentation of the small pellets.

Finally, we should mention that it was sometimes not possible to clearly distinguish between small faecal pellets and organisms distended beyond recognition by one huge food vacuole and therefore resembling a faecal pellet (e.g. Fig. 1e).

\section{DISCUSSION}

Sedimentation of particulate matter compacted into faecal material has been considered to be due only to 
Table 2. Numbers of faecal pellets counted at discrete depths at individual stations along the 4 transects (T1 to T4) during Vestkapp I and II. Counts from 5 to 8 discrete depths are given as mean values between 0 and $100 \mathrm{~m}$; below $100 \mathrm{~m}$ mean values of 2 to 3 discrete depths are listed

\begin{tabular}{|c|c|c|c|c|c|c|c|c|}
\hline \multirow[t]{2}{*}{ Transect } & \multirow[t]{2}{*}{ Depth (m) } & \multicolumn{6}{|c|}{ Station no. } & \\
\hline & & 270 & 269 & 268 & 267 & 271 & 282 & \\
\hline \multicolumn{9}{|c|}{ Vestkapp I } \\
\hline \multirow{7}{*}{$\begin{array}{c}\text { T4 } \\
\text { (north) }\end{array}$} & $0-100$ & 5 & 69 & 68 & 70 & 89 & 15 & \\
\hline & $100-200$ & 0 & 4 & 13 & 11 & & 0 & \\
\hline & $200-300$ & 0 & 10 & 9 & 11 & & & \\
\hline & $300-500$ & 0 & & & & & & \\
\hline & $500-1000$ & 0 & & & & & & \\
\hline & $>1000$ & 0 & & & & & & \\
\hline & & 266 & 265 & 264 & 263 & 262 & & \\
\hline \multirow{7}{*}{ T3 } & $0-100$ & 99 & 74 & 64 & 105 & 214 & & \\
\hline & $100-200$ & 9 & 6 & 7 & 10 & 96 & & \\
\hline & $200-300$ & 9 & 0 & 0 & 0 & 23 & & \\
\hline & $300-500$ & & & & & & & \\
\hline & $500-1000$ & & & & & & & \\
\hline & $>1000$ & & & & & & & \\
\hline & & 261 & 260 & 259 & 258 & 257 & & \\
\hline \multirow{7}{*}{$\mathrm{T} 2$} & $0-100$ & 28 & 55 & 120 & 140 & 9 & & \\
\hline & $100-200$ & & 13 & 20 & & & & \\
\hline & $200-300$ & & 27 & 6 & 20 & 2 & & \\
\hline & $300-500$ & 0 & 2 & 3 & 16 & 38 & & \\
\hline & $500-1000$ & & 0 & & & & & \\
\hline & $>1000$ & & & & & & & \\
\hline & & 256 & 255 & 254 & 253 & 252 & & \\
\hline \multirow{7}{*}{$\begin{array}{c}\mathrm{T} 1 \\
\text { (south) }\end{array}$} & $0-100$ & 20 & 59 & 100 & 30 & 0 & & \\
\hline & $100-200$ & & & 0 & 0 & 0 & & \\
\hline & $200-300$ & & & 0 & 0 & & & \\
\hline & $300-500$ & 0 & & 0 & 0 & 0 & & \\
\hline & $500-1000$ & & & 0 & 0 & & & \\
\hline & $>1000$ & & & 0 & & & & \\
\hline & & 341 & 334 & 333 & 338 & 332 & 331 & 329 \\
\hline \multicolumn{9}{|c|}{ Vestkapp II } \\
\hline \multirow{7}{*}{$\begin{array}{c}\text { T4 } \\
\text { (north) }\end{array}$} & $0-100$ & 0 & 64 & 29 & 60 & 20 & 80 & 10 \\
\hline & $100-200$ & & & 7 & & & 40 & 44 \\
\hline & $200-300$ & & 32 & 8 & 21 & 5 & 12 & 5 \\
\hline & $300-500$ & & & & 6 & 166 & & \\
\hline & $500-1000$ & & 20 & & 10 & 0 & 6 & \\
\hline & $>1000$ & & & & & 0 & & \\
\hline & & & 328 & 327 & 326 & 325 & 324 & \\
\hline \multirow{6}{*}{ T3 } & $0-100$ & & 20 & 10 & 13 & 66 & 25 & \\
\hline & $100-200$ & & & & 38 & 13 & & \\
\hline & $200-300$ & & 0 & & 16 & 0 & 27 & \\
\hline & $300-500$ & & & & 2 & & 73 & \\
\hline & $500-1000$ & & & & & 0 & & \\
\hline & $>1000$ & & & & & & & \\
\hline
\end{tabular}


Table 2 (continued)

\begin{tabular}{|c|c|c|c|c|c|c|c|}
\hline \multirow[t]{2}{*}{ Transect } & \multirow[t]{2}{*}{ Depth (m) } & & \multicolumn{4}{|c|}{ Station no. } & \multirow[b]{2}{*}{319} \\
\hline & & & 323 & 322 & 321 & 320 & \\
\hline \multirow{7}{*}{$\mathrm{T} 2$} & $0-100$ & & 2 & 25 & 25 & 30 & 2 \\
\hline & $100-200$ & & 0 & 0 & & 18 & \\
\hline & $200-300$ & & 0 & 12 & 7 & & \\
\hline & $300-500$ & & & & & 6 & \\
\hline & $500-1000$ & & & & 6 & 0 & \\
\hline & $>1000$ & & & & & 0 & \\
\hline & & 342 & 318 & 317 & 316 & 315 & 314 \\
\hline \multirow{7}{*}{$\begin{array}{c}\text { T1 } \\
\text { (south) }\end{array}$} & $0-100$ & 2 & 0 & 20 & 10 & 43 & 47 \\
\hline & $100-200$ & 0 & 0 & & & & \\
\hline & $200-300$ & & 0 & 3 & 7 & 51 & 10 \\
\hline & $300-500$ & & & & 3 & & 6 \\
\hline & $500-1000$ & & 4 & & & 20 & \\
\hline & $>1000$ & & & & & 11 & \\
\hline & & Ocean & & & & & Coast \\
\hline
\end{tabular}

metazooplankton (Schrader 1971, Honjo \& Roman 1978, Angel 1984). Gowing \& Silver (1985), Gowing (1986) and Riemann (1989) describe a new type of sinking material: the so called 'minipellets' ranging in
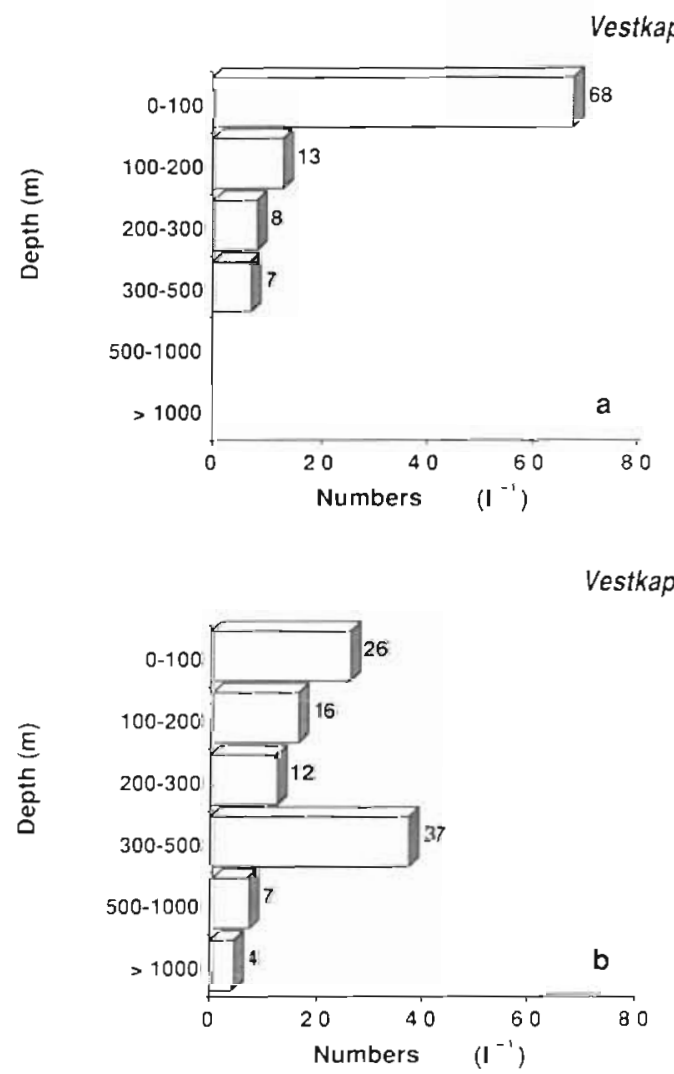

Fig. 2. Vertical distribution of small faecal pellets 130 to 150 um) from (a) Vestkapp I and (b) Vestkapp II in the water column. (Mean values caiculated from Table 2 )
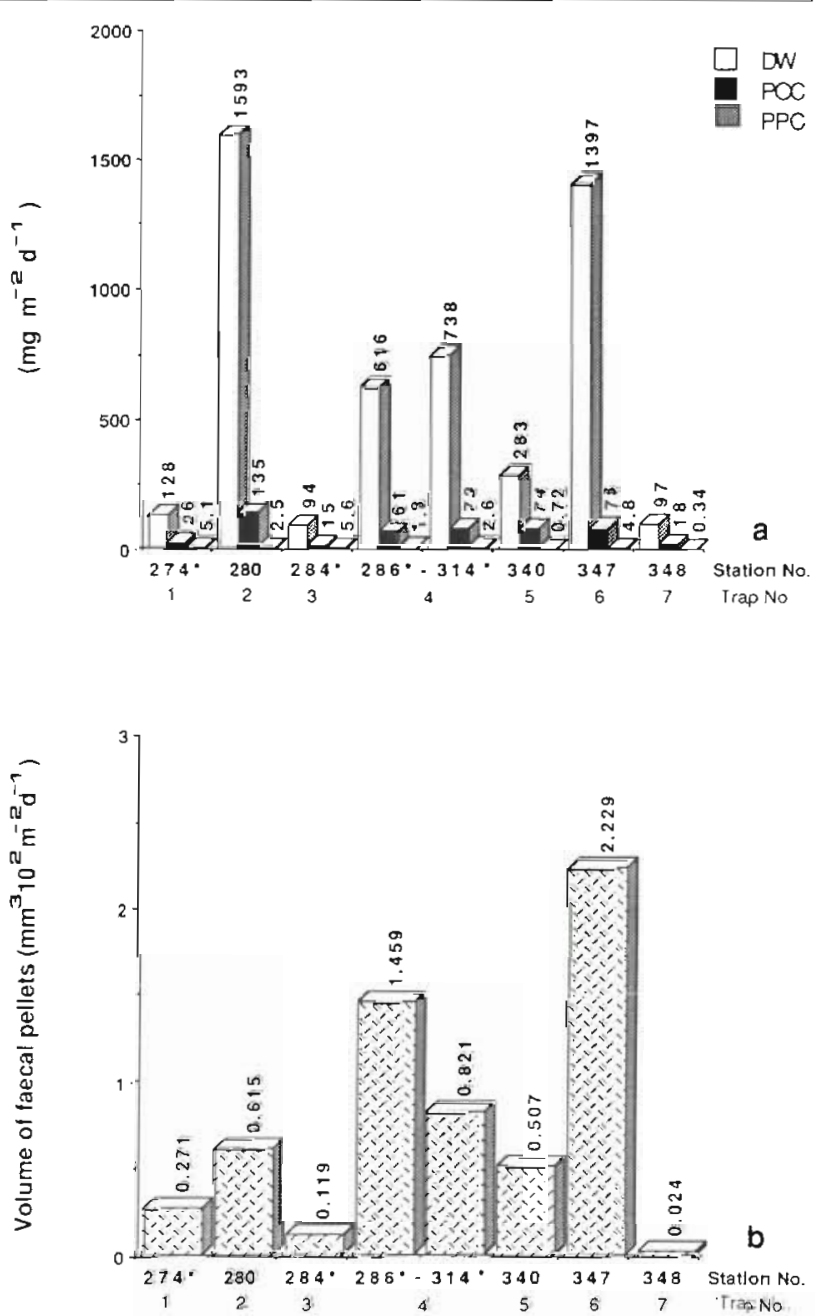

Fig. 3. Sedimentation patterns from the traps $\left(\mathrm{m}^{-2} \mathrm{~d}^{-1}\right)$ at the 7 stations. (a) Dry weight. (DW), particulate organic carbon (POC) and phytoplankton carbon (PPC). (b) Faecal pellet volume. Träp 4: left columin $80 \mathrm{~m}$, right column $350 \mathrm{~m}$; see Table 1) 

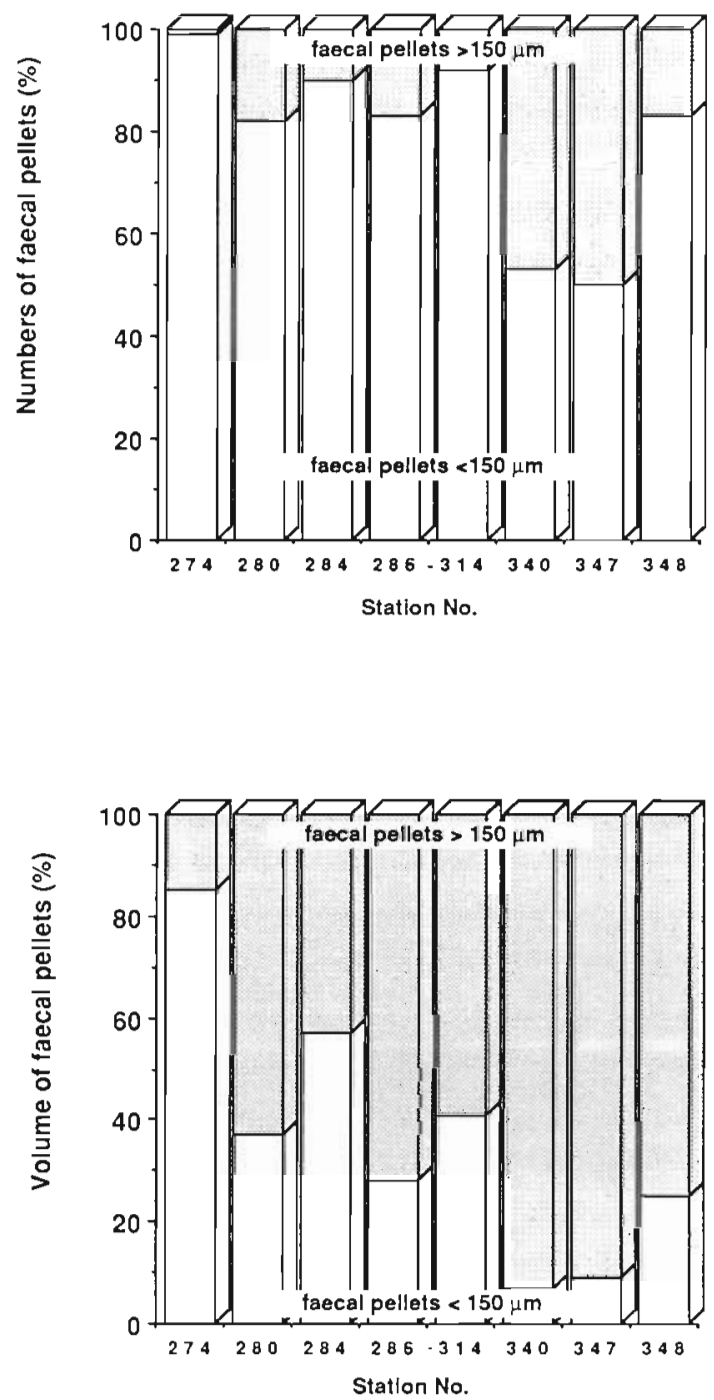

Fig. 4. Relative composition of faecal pellets in the traps during Vestkapp I and II. (a) Numbers of faecal pellets in traps. (b) Volume of faecal pellets in traps. (286-314: left column $80 \mathrm{~m}$, right column $350 \mathrm{~m}$; see Table 1)

size between 3 and $50 \mu \mathrm{m}$ and most probably produced by radiolarians. As other possible producers of minipellets, Gowing \& Silver (1985) mention small hydromedusae and protozooplankters other than radiolarians. The results we obtained from the southeastern Weddell Sea by microscopical examination showed that other protists besides radiolarians could be responsible for production of small pellets. However, the pellets we found belong to the size class 30 to $150 \mu \mathrm{m}$ and therefore should not be called minipellets. We found comparable but somewhat lower numbers of small pellets in the water column as well as in the sedimented material as did Gowing \& Silver (1985) in the North Pacific. In the Weddell Sea Elbrächter (pers. comm.) and Bolt et al. (1988) found large quantities of pellets produced by dinoflagellates.
Dodge \& Priddle (1987) mentioned extrathecal feeding mechanisms as a possibility for the numerous large Antarctic dinoflagellates. Many of the small faecal pellets we observed are very likely to be the product of heterotrophic dinoflagellate and ciliate feeding. Evidence for this assumption is indirect, as the feeding mechanism of heterotrophic protists is only just coming to light. Thus, Gaines \& Taylor (1984) and Jacobson \& Anderson (1986) report that the common dinoflagellate genus Protoperidinium feeds voraciously on diatoms by means of a velum which envelopes the prey outside the cell body. However, the fate of the remains is not mentioned. Bolt et al. (1988) and Gaines (pers. comm.) and Elbrächter (pers. comm.) observed the egestion products of dinoflagellates that fed by ingesting diatoms. The empty frustules were wrapped in a sheet very similar to the objects we are discussing here. Even less is known about faeces production by phagotrophic ciliates in the marine pelagic environment (Stoecker 1984), although they are also known to feed on large diatoms and other large organisms (Smetacek 1981; see Fenchel 1987 for review). We also observed some ciliates and even large tintinnids with ingested cells in our samples.

Although we cannot identify the protistan producers of the small faecal pellets, we do feel that we can rule out the possibility that metazoans were the producers. Metazoan numbers were low during the investigation and their faeces are known to be of altogether different shapes and composition. Thus, copepods and krill faeces are sausage or thread-shaped, respectively, and invariably contain crushed frustules and unidentifiable detritus (e.g. Turner \& Ferrante 1979, von Bodungen et al. 1987). In addition there is confusion in the literature regarding the metazoan origin of the various faecestype particles found in the sea. The faecal pellets attributed to copepods by Schrader (1971, Fig. 1) from water column samples collected in the Baltic were definitely not produced by a calanoid copepod. Rather, the round shape, the intact frustules and the presence of a distinct sheet-like membrane suggest a protistan rather than a metazoan producer. In this connection we add that only dinoflagellates or ciliates could have produced these pellets as there are no pelagic forams or radiolarians in the Baltic.

The fate of the small faecal pellets in the deep water column is as yet unknown as our deepest sediment trap was deployed in $350 \mathrm{~m}$ and the Weddell Sea is mostly $4000 \mathrm{~m}$ deep. However, during Vestkapp II some small faecal pellets were found even below $1000 \mathrm{~m}$ in the water column. An indication that the small faecal pellets indeed settled out of the water column is that we found the smaller faecal pellets during Vestkapp II in greater depth than during Vestkapp I. Further, diatom frustules wrapped in membranes are better protected 
from dissolution than unprotected ones, as demonstrated by Schrader (1971) for similar pellets. Therefore, protistan faecal pellets should be an effective transport vehicle of intact diatom frustules to depth. However, the investigation area off Vestkapp is characterized by a strong coastal current in the upper $100 \mathrm{~m}$; faecal pellets found in the deeper water could hence have been produced at those depths. We also cannot rule out disintegration of most of the small pellets on their way downward to the sea floor.

Sedimentation in the central Weddell Sea is very low in comparison to other regions in the Southern Ocean and to other oceans (Fischer et al. 1988). Trap material from a year-long deployment at $3880 \mathrm{~m}$ water depth yielded a maximum sedimentation rate $(9.2 \mathrm{mg}$ dry wt $\mathrm{m}^{-2} \mathrm{~d}^{-1}$ ) during mid March (Fischer et al. 1988). The peak of maximum sedimentation at $863 \mathrm{~m}$ was rather sharp and for the rest of the year vertical particle flux was negligible to non-existent. The composition of this material as observed under the microscope resembled, in general, material collected in our traps. However, the small faecal pellets, mentioned in this paper, were apparently absent. The faecal pellets found in the deep traps contained frustules of various centric and pennate diatoms that were still intact, but the faecal pellet size was more than $500 \mu \mathrm{m}$.

In the southeastern Bransfield Strait, traps deployed to date have collected primarily krill faeces and the flux rates were much higher (von Bodungen 1986, von Bodungen et al. 1986, von Bodungen et al. 1987, Wefer et al. 1988). Strings of krill faeces dominated the trap material during the peak of the sedimentation. This maximum in sedimentation was earlier than that observed in the Weddell Sea and daily flux rates exceeded those in the Weddell Sea by a factor of 100 . As krill swarms are not common in the central Weddell Sea (Marr 1962), vertical flux here differs from that in the krill-rich areas. In the absence of krill it appears that the relative role of protistan faecal pellets increases, although the magnitude of the total flux is low. Whether the presence or absence of krill is related to productivity is yet unclear. Interest in pelagic protozoa is increasing with the realization of their important role in the system; their faecal products must accordingly also be of importance and should hence receive closer attention.

Acknowledgements. Thanks are due to the crew of the RV 'Polarstern' and to Prof. Hempel as chief scientist of the cruise. We are grateful to $\mathrm{V}$ Smetacek, U. Bathmann, K. Buck, M. Gowing, R. Scharek and G. Dieckmann for their helpful critical comments on the content and the English of the manuscript, as well as 0 . Holm-Hansen and 2 other unknown reviewers. This work was supported by the Deutsche Forschungsgemeinschaft (Bo 768/1).

\section{LITERATURE CITED}

Alldredge, A. L., Gotschalk, C. C., Macintyre, S. (1987). Evidence for sustained residence of macrocrustacean fecal pellets in surface waters off Southern California. Deep Sea Res. 34: 1641-1642

Angel, M. V. (1984). Detrital organic fluxes through pelagic ecosystems. In: Fasham, M. J. R. (ed.) Flows of energy and materials in marine ecosystems. Nato Conference Series IV Mar. Sci. 13. Plenum Press, New York, p. 475-516

Bathmann, U. V. (1988). Mass occurrence of Salpa fusiformes in the spring of 1984 off Ireland: implications for sedimentation processes. Mar. Biol. 97: 127-135

Bathmann, U. V., Noji, T T., Peinert, R., Voss, M. (1987). Copepod faecal pellets: abundance, sedimentation and content at a permanent station in the Norwegian Sea in May/June 1986. Mar. Ecol. Prog. Ser. 38: 45-51

Bodungen, B. von (1986). Phytoplankton growth and krill grazing during spring in the Bransfield Strait, Antarctica implications from sediment trap collections. Polar Biol. 6: $153-160$

Bodungen, B. von, Fischer, G., Nöthig, E.-M., Wefer, G. (1987). Sedimentation of krill faeces during spring development of phytoplankton in Bransfield Strait, Antarctica. In: Degens, E. T., Honjo, S., Izdar, E. (eds.) Particle flux in the ocean. Mitt. Geol.-Palaeontol. Inst. Univ. Hamburg, SCOPE UNEP, Sonderband 62: 243-257

Bodungen, B. von, Nöthig, E.-M., Sui, Q. (1988). New production of phytoplankton and sedimentation during summer 1985 in the southeastern Weddell-Sea. J. comp. Biochem. Physiol. 90B: 475-487

Bodungen, B. von, Smetacek, V S., Tilzer, M. M., Zeitzschel, B. (1986). Primary production and sedimentation during spring in the Antarctic Peninsula region. Deep Sea Res. 33: $177-194$

Bolt, P. A., Buck, K. R., Garrison, D. L. (1988), A phagotrophic dinoflagellate associated with sea ice communities in the Weddell Sea, Antarctica. Abstract. J. Phycol. 24 (S): 12

Dodge, J. D., Priddle, J. (1987). Species composition and ecology of dinoflagellates from the Southern Ocean near South Georgia. J. Plankton Res. 9: 685-697

Dunbar, R. B. (1984). Sediment trap experiments on the Anarctic continental margin. Antarct. J. U.S. 19: 70-71

Edler, L. (ed.) (1979). Recommendations on methods for marine biological studies in the Baltic Sea. Phytoplankton and chlorophyll. BMB (Baltic Marine Biologists) Publ. 5: $1-38$

Fenchel, T (1987). Ecology of protozoa. Science Tech. Inc., Madison, Wisconsin. Springer-Verlag, Berlin, p. 1-196

Fischer, G., Fütterer, D. Gersonde, R., Honjo, S., Ostermann. D., Wefer, G. (1988). Seasonal variability of particle flux in the Weddell Sea and its relation to ice cover. Nature, Lond. 335: $426-428$

Fukuchi, M., Sasaki, H. (1981). Phytoplankton and zooplankton standing stocks and downward flux of particulate material around fast ice edge of Luzow-Holm Bay, Antarctica. Mem natn. Inst. Polar Res., Tokyo Ser E 34: 13-36

Gaines, G., Taylor, F. R. J. (1984). Extracellular digestion in manne dinoflagellates. J. Plankton Res. 6: 1057-1061

Gowing, M. M. (1986). Trophic biology of phaeodarian and flux of living radiolarians in the upper $2000 \mathrm{~m}$ of the North Pacific central gyre. Deep Sea Res. 33: 655-674

Gowing, M. M., Silver, M. W. (1985). Minipellets: a new and abundant size class of marine fecal pellets. J. mar. Res. 43. 395-418

Hempel G. (1985). Die Expedition ANTARKTIS III mit FS 'Polarstern' 1984/1985. Ber Polarforsch. 25, p. 1-209 
Hewes, C. D., Holm-Hansen, O., Sakshaug, E. (1985). Alternate carbon pathways at lower trophic levels in the antarctic food web. In: Siegfried, W. W., Condy, P. R., Laws, R. M. (eds.) Antarctic nutrient cycles and food webs. SpringerVerlag, Berlin, p. 277-283

Honjo, S., Roman, M. (1978). Marine copepod fecal pellets: production, preservation and sedimentation. J. mar Res. 36: 45-57

Hubold, G., Hempel, I., Meyer, M. (1988). Zooplankton communities in the southern Weddell Sea (Anarctica). Polar Biol. 8: 225-233

Jacobson, J. M., Anderson, D. M. (1986). Thecate heterotrophic dinoflagellates feeding behavior and mechanisms. J. Phycol. 22: 249-258

Lampitt, R. S., Noji, T., Bodungen, B. von (1989). What happens to zooplankton faecal pellets? Implications for material flux. Mar. Biol: in press

Lenz, J. (1971). Zur Methode der Sestonbestimmung. Kieler Meeresforsch. 27: 180-193

Marr, J. W. S. (1962). The natural history and geography of the Antarctic krill (Euphausia superba Dana). 'Discovery' Rep. 32: $33-464$

Nöthig, E.-M. (1988). Untersuchungen zur Ökologie des Phytoplanktons im südöstlichen Weddellmeer im Januar/Februar 1985 (Antarktis III, 3). Ber. Polarforsch. 53, p. 1-118

Pilskaln, C. H., Honjo, S. (1987). The fecal pellet fraction of biogeochemical particle flux to the deep sea. Global Biogeochem. Cycles 1: 31-48

Riemann, F. (1989). Gelatinous phytoplankton detritus aggregates on the Atlantic deep-sea bed. Structure and mode of formation. Mar. Biol. 100: 533-539

This article was submitted to the editor
Schnack, S. B. (1985). A note on the sedimentation of particulate matter in Antarctic waters during summer. Meeresforsch. 30: 306-315

Schrader, H.-J. (1971). Fecal pellets: role in sedimentation of pelagic diatoms. Science 174: 55-56

Smetacek, V (1980). Zooplankton standing stock, copepod faecal pellets and particulate detritus in Kiel Bight. Estuar coast. mar. Sci. 11:477-490

Smetacek, V. (1981). The annual cycle of protozooplankton in the Kiel Bight. Mar. Biol. 63: 1-11

Smetacek, V (1984). The supply of food to the benthos. In Fasham, M. J. R. (ed.) Flows of energy and materials in marine ecosystems. Nato Conference Series IV Mar. Sci. Plenum Press, New York, p. 517-548

Stoecker, D. K. (1984). Particle production by planktonic ciliates. Limnol. Oceanogr 29: 930-940

Strathmann, R. R. (1967). Estimating the organic carbon content of phytoplankton from cell volume or plasma volume. Limnol. Oceanogr. 12: 411-418

Turner, J. T., Ferrante, G. G. (1979). Zooplankton fecal pellets in aquatic ecosystems. Bioscience 29: 670-677

Utermöhl, H. (1958). Zur Vervollkommnung der quantitativen Phytoplankton-Methodik. Mitt. int. Verein theor. angew Limnol. 9: 1-38

Wefer, G., Fischer, G., Fütterer, D., Gersonde, R. (1988). Seasonal particle flux in the Bransfield Strait (Antarctica). Deep Sea Res. 35: 891-899

Zeitzschel, B., Diekmann, P., Uhlmann, L. (1978). A new sediment trap. Mar. Biol. 45: 285-288

Manuscript first received: February 28, 1989

Revised version accepted: June 5, 1989 